$18: 306$

<原 著 $>$

$\mathrm{B}$ 型慢性肝炎でのインターフェロソ療法の有効性の評価

ーインターフェロン投与前後の肝組織所見を中心に一

\begin{tabular}{|c|c|c|}
\hline 雄* & 進藤 & 道子 \\
\hline 誠 & 新井 & 賢 \\
\hline
\end{tabular}

要 旨：インターフェロン(IFN) 治療を行った B 型慢性肝炎 (CHB) の肝生検組織からみた IFN の有效性の評価を行った。対象は組織学的に CHB と診断された25例(CAH 11例, CAHcBN 10例，CPH 3 例，CAHčLC 1 例) である。治療前の DNA-P 拈よび HBeAg は全例で陽 性であった。 IFN の使用総量は $0.95 \sim 4.77 \times 10^{8} \mathrm{IU}$ であり，原則として 4 週間連日投与で行っ た。治療後に HBeAgが持続的に陰性化した有効群は10例, HBeAg が持続的に陽性ないしは一 過性に陰性化した無効群は15例であった。治療前の組織所見のらち有効群で多く認められたも のには piecemeal necrosis (PN), bridging necrosis (BN) 括よび肝細胞の庫大があり,この 5ち PN と BN は推計学的にも有意に高率 $(\mathrm{p}<0.01$ と $<0.05)$ であった。 また，上記組織所 見を 2 つ上認める CHB では高率にIFN が有効であった。治療後の肝生検では有効群で組織 所見の著明な改善を認めた．また，HBeAg 陽性例でも SGPT の正常化する例では組織所見の 改善が認められた。

索引用語： $\mathrm{B}$ 型慢性肝炎 インターフェロン 肝生検

はじめに

B 型慢性肝炎で hepatitis B virus (HBV) の活発な 堌殖を㧕制し $\mathrm{HBe}$ 抗原の陰性化ないしは $\mathrm{HBe}$ 抗体 への seroconversionを認める例では肝炎の鎮静化が 認められる1".

1976年飞 Greenberg ら $ら^{2)}$ とって B 型慢性肝炎に 対してインターフェロン(IFN)が投与されてからすで に11年が経過した。その間, IFN 療法後の HBV 関連 マーカーの推移に関しては多くの報告がみられる3-5) が, IFN 投与前後の肝組織所見を検討した知見は乏し い.

今回，著者らは B 型慢性肝炎での IFN の有効性を 評価する目的で IFN 療法後の $\mathrm{HBe}$ 抗原・抗体系の推 移からみた IFN 投与前の肝組織所見の検討と IFN 投 与前後の肝組織所見の推移を検討し若干の知見を得た ので報告する.

\section{対象および方法}

教室で過去 5 年間に組織学的に B 型慢性肝咨と診 断され, IFN 治療を受けたもののうち治療終了後 1 年

* 明石市立市民病院内科

**京都府立医科大学第 3 内科

<受付日62年 7 月 2 日 $>$
以上経過観察されている25症例を対象とした。 全例で IFN 投与前の HBe 抗原执よびDNA ポリメラーゼ (DNA-P)は陽性である. 性別は男性21例, 女性 4 例で ある.年龄は22歳から47歳で平均年齢は33歳であった。 IFN 治療前の組織診断は慢性肝炎活動性 (CAH) 11 例，慢性持続性肝炎 (CPH) 3 例, CAH̄ bridging necrosis (BN) 10例, CAHc̄ cirrhosis 1 例であった.

使用した IFN は IFN- $\alpha$ (日赤) 8 例, IFN- $\beta$ (東レ) 6 例, IFN- $\beta$ (持田) 2 例, HLBI (ウエルカム・住友) 4 例, $\gamma$-IFN- $\alpha \mathrm{A}$ (ロッシュ・武田) 2 例, $\gamma$-IFN- $\alpha 2 \mathrm{~b}$ （エセックス・山之内） 1 例である. IFN の総投与量 は IFN- $\alpha 0.95 \sim 4.77 \times 10^{8}$ 国際単位 (IU)，IFN- $\beta$ (東 V) $1.02 \times 10^{8} \mathrm{IU}, \mathrm{IFN}-\beta$ (持田) $1.05 \times 10^{8} \mathrm{IU}, \mathrm{HLBI}$ $1.68 \sim 2.10 \times 10^{8} \mathrm{IU}, \gamma$-IFN- $\alpha \mathrm{A} 4.77 \times 10^{8} \mathrm{IU}, \gamma$-IFN$\alpha 2 \mathrm{~b} 1.68 \times 10^{8} \mathrm{IU}$ である. 投与方法は IFN- $\alpha, \gamma$-IFN$\alpha \mathrm{A}, \gamma$-IFN- $\alpha 2 \mathrm{~b}$ おょび HLBI は筋注で, IFN- $\beta$ は静 注で行った。投与期間は原則として連日投与により 28 日から52日間である。 また，HLBI を投与した 2 例で $6 \times 10^{8} \mathrm{IU}$ を 1 週間連日投与後 1 週間休薬する短期間 歇投与法を 4 サイクル反復し, 総投与量 $1.68 \times 10^{8} \mathrm{IU}$ を使用した。

肝生検組織の検討はーマトキシリン・エオジン染色, 
Table 1 Histological Features Assessed.

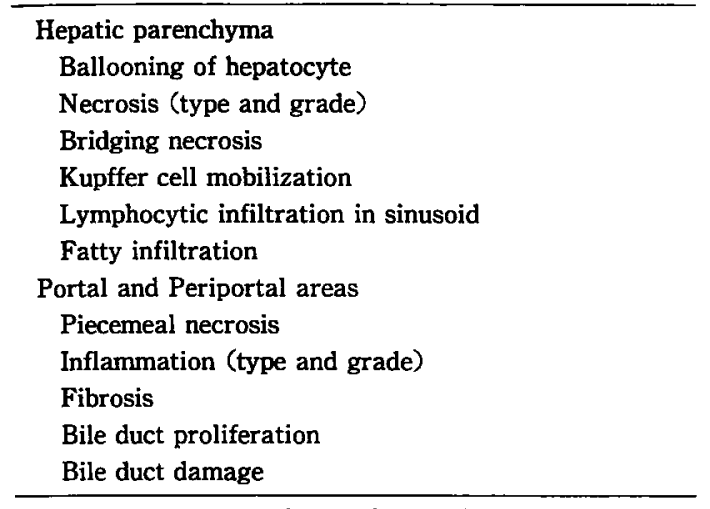

histological grade: 0 (normal) to +3 (severe)

Trichrome 染色および細網線䧽染色標本を中心に Table 1 のごとく肝小葉内病変と門脈域および門脈域 周囲病変につきそれぞれの所見を0 (正常) +1 （軽 度),+2 (中等度),+3 (高度) の 4 段階に分けて検 討した. 肝生検標本の総数は35例である。 また, IFN 治 療前後で肝生検が施行されたのは 8 例である。そのう ち， 2 例で盰生検が 3 回施行された.

治療効果の判定は IFN 治療終了後 1 年以内に $\mathrm{HBe}$ 抗原が持続的に陰性化したものないしは $\mathrm{HBe}$ 抗体へ seroconversion したものを有効群とした．また，HBe 抗原が一過性に消失したものや持続陽性のものを無効 群とした。
HBe 抗原・抗体は radioimmunoassay 法により測 定し，その判定は鈴木ら ${ }^{6 /}$ の判定に従った. データーの 解析はStudent の $\mathrm{t}$ 検定, 怙よび $\chi^{2}$ 険定を用いた。

\section{成 績}

IFN 治療終了後 1 年以内に HBe 抗原が持続的に陰 性化ないしは HBe 抗体へ seroconversion した有効 群は10例であった．また，HBe 抗原が一過性に陰性化 したものや持続的に陽性であった無効群は15例であっ た.

一方，IFN 投与前の HBV マーカーに関して有効群 での HBe 抗原の cut off 值 (mean $\pm \mathrm{SD})$ は5.1 \pm 2.2 , 無效群のそれは4.4土1.2であった. DNA-P 活性は有 効群で $600 \pm 1,260(\mathrm{dpm})$, 無効群で $860 \pm 1,498(\mathrm{dpm})$ であり，HBe 抗原およびDNA-P 活性ともに両群間で 推計学的な有意差は認めなかった。

1. インターフェロン投与前の肝組織所見

a. 門脈域および門脈域周囲病変 (Fig. 1) piecemeal necrosis (PN) は有効群10例全例 (100\%) に認め，その程度は軽度 $27.3 \%$ ，中等度 $18.2 \%$, 高度 54.5\%であった，一方，無効群15例での PN は65\%に

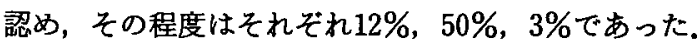
また，無効群の $35 \%$ PNを認めず，有効群で PN が 有意に高率 $(\mathbf{p}<0.01)$ に認められ，その程度も強いむ のが多かった（Fig.1, 3).

炎症性細胞浸潤は有效群, 無効群ともに $100 \%$ に認め た。その程度は有効群で軽度 $27 \%$, 中等度 $27 \%$, 高度

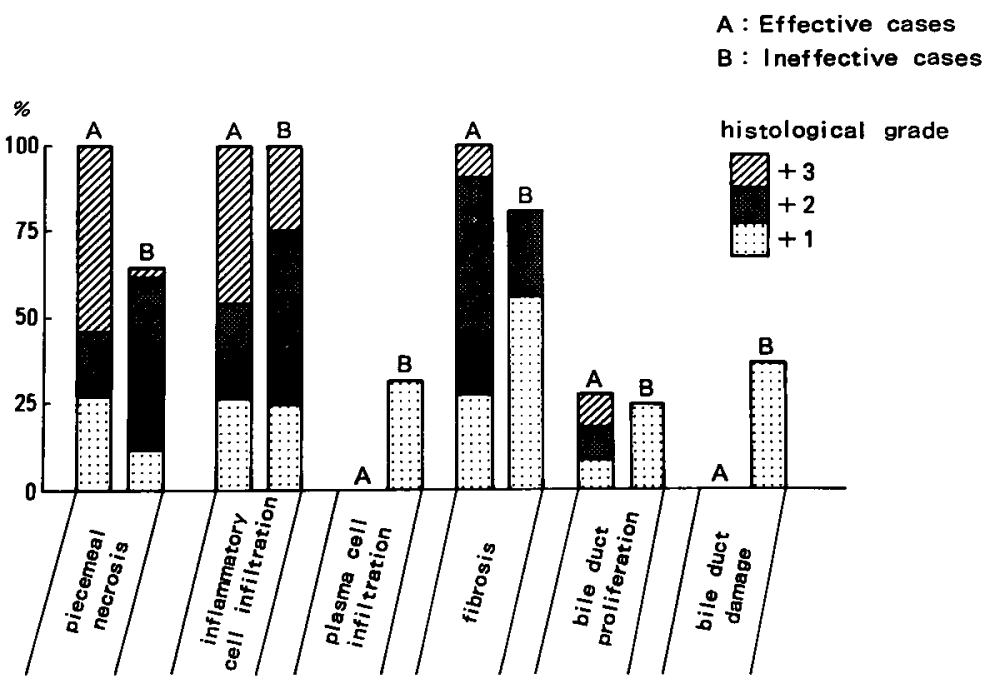

Fig. 1 Pretreatment histological features of periportal and portal areas of effective and ineffective cases to interferon treatment. 


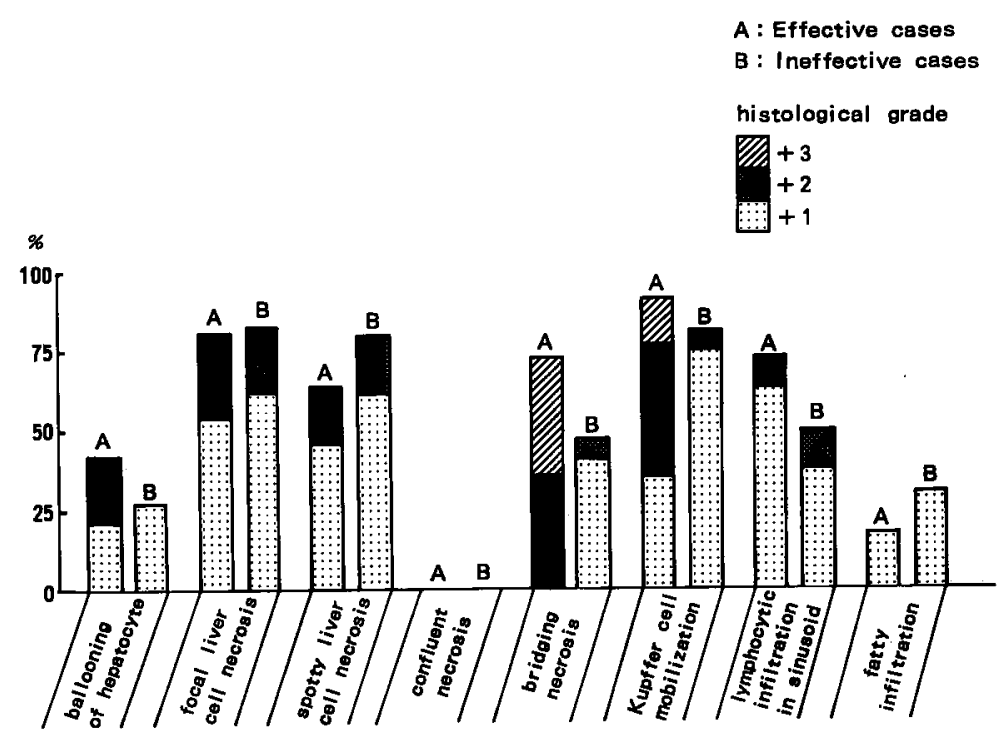

Fig. 2 Pretreatment histological features of hepatic parenchyma of effective and ineffective cases to interferon treatment.

46\%であり，無効群のそれはそれぞれ $25 \%, 50 \%, 25 \%$ であった。また，形質細胞浸潤は有効群では認められ ず，無効群では32\%に認めたが，その程度は軽度であ ク，無效群で有意に高率に認められた（Fig. 1)。門脈 域の線維増生は有効群で100\%に認め, その程度は軽度 $27.3 \%$ ，中等度 $63.6 \%$ ，高度 $9.1 \%$ であった，一方，無 効群では81.2\%に認め，その程度は軽度 $56.2 \%$ ，中等 度25\%であった．無効群の $18.8 \%$ に線維増生を認めな かった，胆管増生は有効群で $27.3 \%$ に認め，その程度 は軽度，中等度，高度がそれぞれ9.1\%であった。 また， 72.7\%に胆管増生を認めなかった，一方，無効群では 25\%に胆管増生を認め，その程度は軽度であり，75\% に胆管増生を認めなかった（Fig. 1)。

胆管異常は有効群では 1 例も認めず，無効群では 37.5\%に認めたが，その程度はいずれも軽度であった (Fig. 1).

b. 肝小葉内病変 (Fig. 2)

肝細胞の腫大は有效群10例のうち $40 \%$ に認め，その 程度は軽度および中等度がそれぞれ20\%であった。一 方，無効群15例では26.6\%に認め，その程度はすべて 軽度であった (Fig. 2). 従って, 肝細胞の腫大は有効 群で高率に認めるも両群で推計学的な有意差は認めな かった (Fig. 4). focal necrosisは有効群で81.8\%に 認め，その程度は軽度 $54.5 \%$ ，中等度27.3\%であった。 無効群です83\%に認め,その程度はそれぞれ63\%と

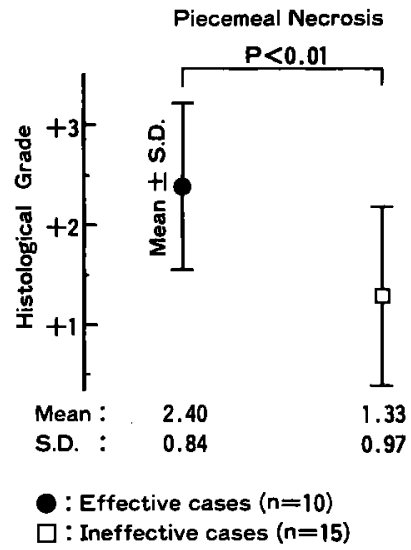

Fig. 3 Significance of piecemeal necrosis in the pretreatment liver biopsy in relation to the efficacy of interferon treatment.

20\%であった。

また， spotty necrosis は有効群で64\%に認め，その 程度は軽度 $46 \%$ ，中等度18\%であった。無効群では $80 \%$ に認め，その程度はそれぞれ62\%と18\%であった.confluent necrosisは両群で 1 例も認められなかった。 BN は有効群で70\%に認め，その程度は中等度および 高度がそれぞれ30\%と40\%であった。一方，無効群で は46.6\%に認め，その程度は軽度および中等度がそれ 


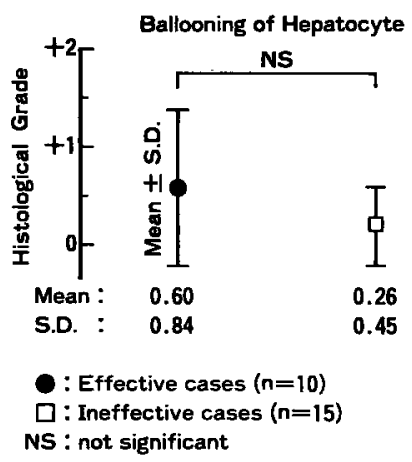

Fig.4 Significance of ballooning of hepatocyte in the pretreatment liver biopsy in relation to the efficacy of interferon treatment.

ぞれ33.3\%と13.3\%であり，有効群で有意に高率 $(\mathrm{p}<$ 0.05）に認められた（Fig. 2,5). Kupffer 細胞の動員 は有効群で91\%に認め，その程度は軽度 $36.5 \%$ ，中等 度 $45.5 \%$, 高度 $9.0 \%$ であった。無効群では $81 \%$ に認め, その程度は軽度 $75 \%$, 中等度6\%であった。 また，類洞 内のリンハ・球浸潤は有効群で $72.7 \%$ に認め，その程度 は軽度63.6\%, 中等度9.1\%であった. 無効群では50\% に認め,その程度はそれぞれ37.5\%と12.5\%であった。 脂肪沈着は有効群と無効群でそれぞれ18.2\%と $31.2 \%$ に認め，その程度はすへてて軽度であった（Fig. 2).

2. インターフェロンが有効な肝組織所見 (Fig. 6) 有効群と無効群の間で差の認められた組織所見の5 ち肝緇胞の董大，BN および PN の 3 つの組織所見の 有用性について有効群之無效群で推計学的な検討を 行った。有效群では肝細胞の尰大, BN およびPNの3

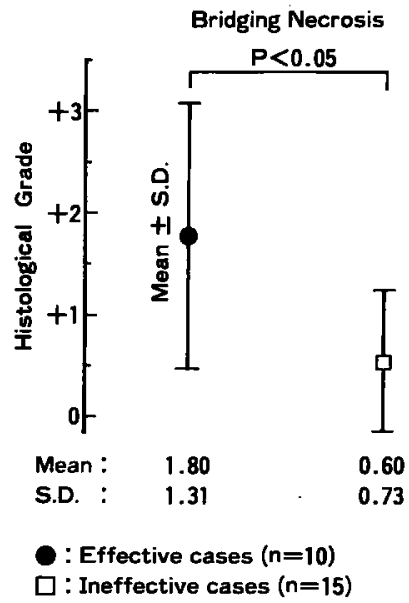

Fig. 5 Significance of bridging necrosis in the pretreatment liver biopsy in relation to the efficacy of interferon treatment.

つの所見をすべて有する例の組織スコフーは4.80士 2.44 で無効群の $2.20 \pm 1.78$ に比し，有意に高い（p< 0.01) 組織スコアーが得られた (Fig. 6). また，上記 3 つの組織所見のうち PN と BN の 2 つの所見を有 する組織スコフーは有効群で $4.20 \pm 2.09$ と無効群の $1.93 \pm 1.57$ K比し，有意に高く $(\mathrm{p}<0.01), \mathrm{PN}$ 之肝細 胞の腫大についても有効群で3.00土1.33と無効群の $1.60 \pm 1.18$ に比し，有意に高率（p<0.05）であった (Fig. 6).

従って，BN，PN および肝細胞の腫大といった組織 所見を 2 つ上有する例では推計学的にも有意に

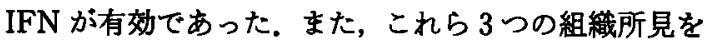

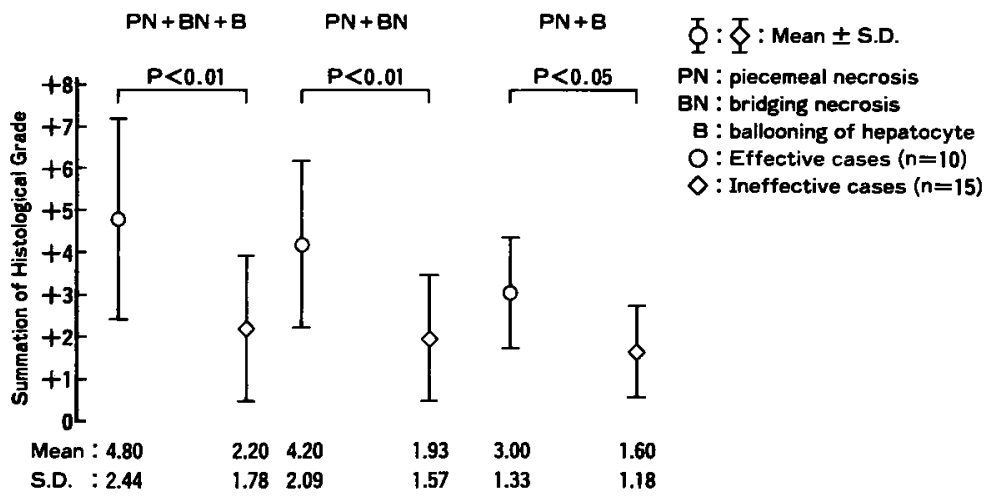

Fig. 6 Significance of the combined histological features of piecemeal necrosis, bridging necrosis and/or ballooning of hepatocyte in relation to the efficacy of interferon treatment. 


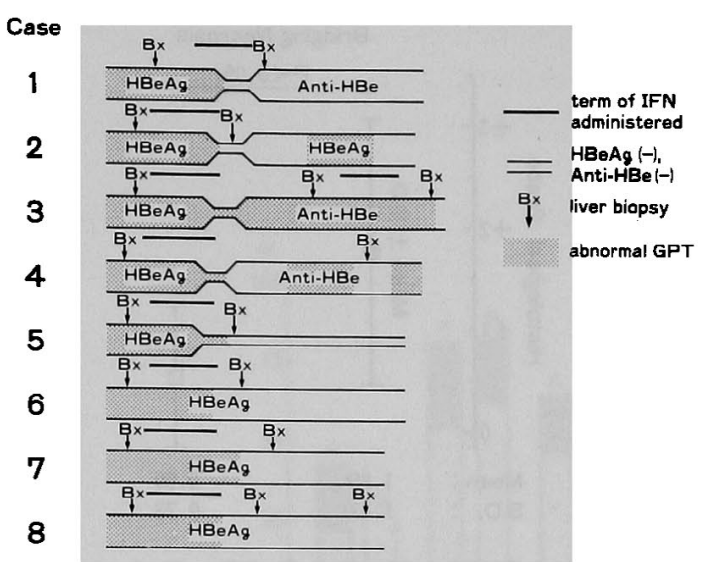

Fig. 7 Course of $\mathrm{HBeAg}$ /anti-HBe and SGPT in 8 patients who underment follow-up liver biopsy after interferon treatment.

K. A. $28 y / 0$, Male (CAHĒBN, typeB)

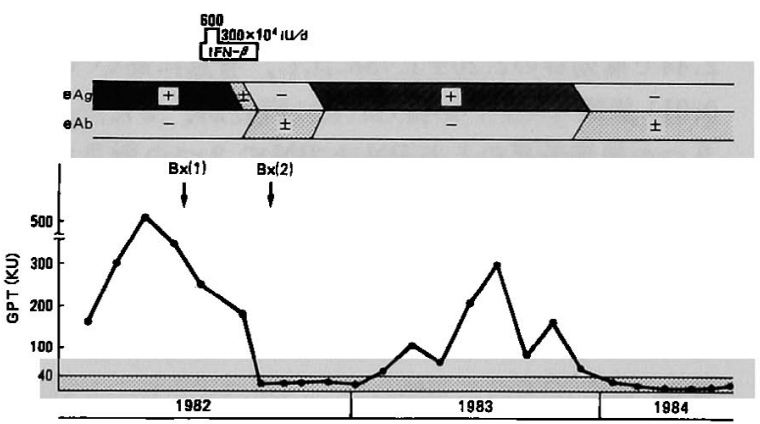

Fig. 8 Clinical course of a 28 year-old man with chronic active hepatitis with bridging hepatic necrosis, type $B$ (case 2), who had received interferon- $\beta$ treatment and then $\mathrm{HBeAg}$ disappeared with normalization of SGPT. Two liver biopsies were done once before the interferon treatment and another at the time of the normalization of SGPT after the interferon treatment.

認めない例ではIFN が有効な例は認めなかった。

3. インターフェロン治療前後の肝組織所見の検討 (Fig. 7)

IFN 治療前後で肝生検が施行されたのは 8 例（有効 群 4 例, 無効群 4 例) であった. IFN 治療前の組織診 断は CAHc̄BN 4 例, CAH 4 例であった。

IFN 治療後 3 例（case 1，5，7）で CAHc̄BN から CAH への改善がみられた。をた，1例（case 2, Fig. 8,9,10) で CAHc̄BN から CPH への改善がみられた。

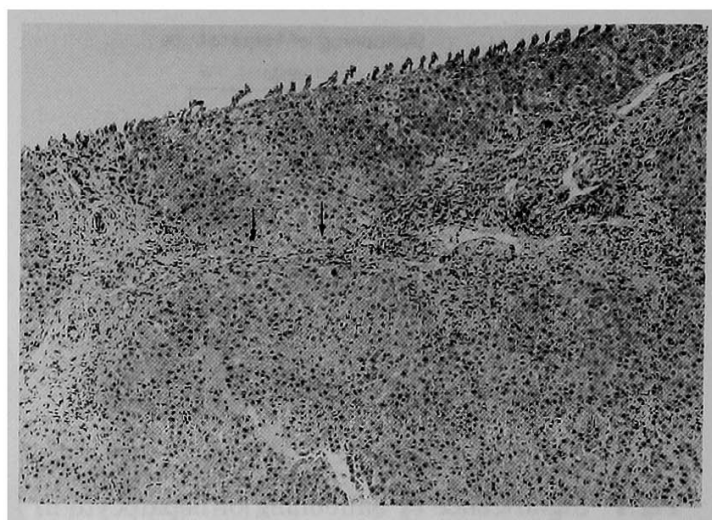

Fig. 9 Histological picture of the first liver biopsy of the case 2 . The biopsy was done before the interferon treatment. Portal tract is enlarged and heavily infiltrated with prominent piecemeal necrosis. Two adjacent portal tracts are located closely and connected with narrow bridging hepatic necrosis (shown as arrows). HE $\times 25$

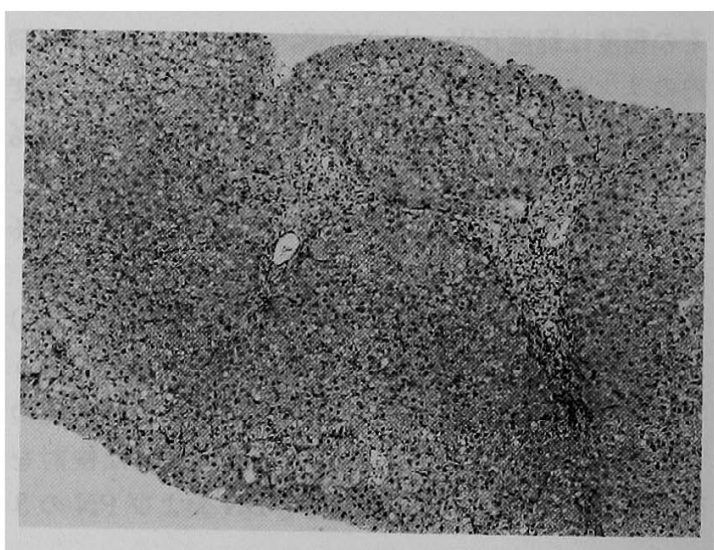

Fig. 10 Histological picture of the second liver biopsy of the case 2 . The biopsy was done when HBeAg disappeared and SGPT become normalized. Portal tract become smaller with marked improvement of inflammatory cell infiltration. Piecemeal necrosis disappeared. HE $\times 25$

他の 1 例 (case 8) では CAH から CPH への改善が認 められた。一方, CAH の 2 例 (case 4,6) でIFN 治 療後も組織学的には依然 CAHであったが，肝実質内 の壊死巣の改善やPN と門脈域の炎症性細胞浸潤の 著しい改善が認められた。

また，1例（case 3）では IFN 治療後に HBe 抗体 への seroconversion が認められたが，血清トランスフ ミナーゼの異常が持続した．本例では $\mathrm{HBe}$ 抗体への 
M.N. 34 y.o, male

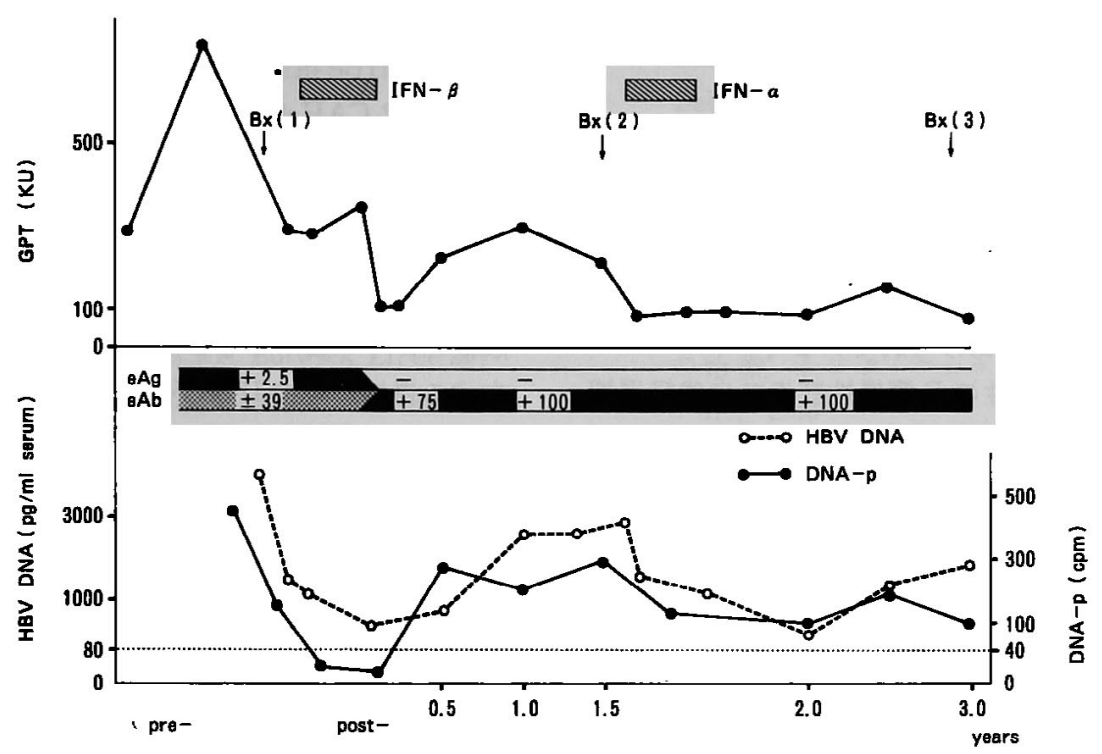

Fig. 11 Clinical course of a 34 year-old man with chronic active hepatitis, type $\mathrm{B}$ (case 3). He lost $\mathrm{HBeAg}$ and seroconverted to anti-HBe after interferon treatment. Anti-HBe remained positive, but SGPT sustained abnormal even after anti-HBe seroconversion. Both DNA-P and HBV DNA were persistently positive. Three liver biopsies were done.

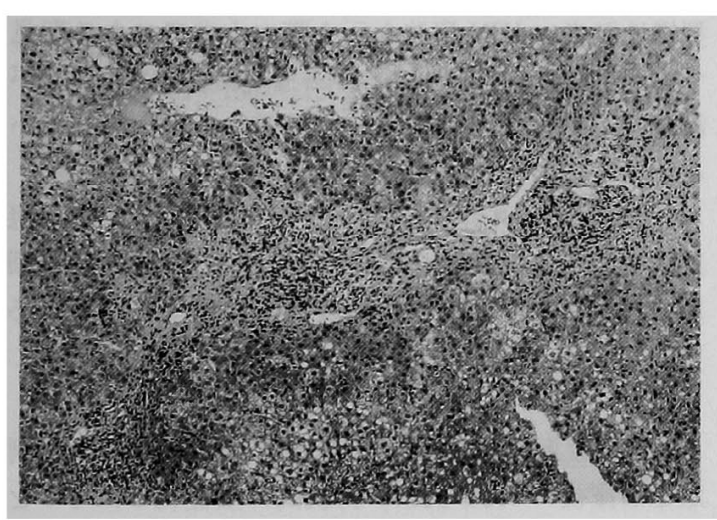

Fig. 12 Histological picture of the first liver biopsy of the case 3 . The biopsy was done before interferon treatment. Portal tract is enlarged and heavily infiltrated. Piecemeal necrosis is also prominent. $\mathrm{HE} \times 25$

seroconversion 後の肝生険で CAHから CAHc̄BN への組織学的悪化が認められた (Fig. 11, 12, 13).

組織学的に改善の認められた例ではいずれる HBe 抗原の陰性化 (case 2,5) や $\mathrm{HBe}$ 抗体への seroconversion (case 1,4)がみられた。 しかし，HBe抗原が

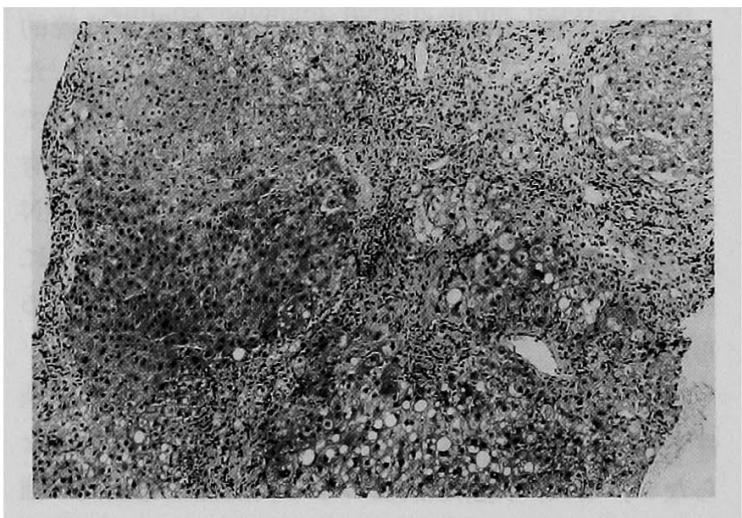

Fig. 13 Histological picture of the second liver biopsy of the case 3 . The biopsy was done at the time of positive anti-HBe in serum, but when SGPT sustained abnormal. Portal tract is enlarged and contains heavy inflammatory cell infiltration. Piecemeal necrosis is prominent. Portal to portal and portal to central bridging hepatic necrosis are also seen. There was histological aggravation in the second liver biopsy despite the presence of anti-HBe. $\mathrm{HE} \times 25$ 
持続的に陽性の 3 例（case 6,7,8）でも組織学的な改 善が認められたが, 全例で IFN 治療後に血清トランス アミナーゼの正常化が認められた（Fig. 7).

\section{考案}

B 型慢性肝炎に対してIFN 療法が行われてから約 11年が経過した ${ }^{2}$. その間に IFN 療法が有効な B 型慢 性肝炎として 1）女性；2）治療前の DNA-Pの低值，

3）慢性肝炎活動性，4）IFN 投与前にステロイド治療 の既往を有することがあげられている7?.

一方, $\mathrm{HBe}$ 抗原陽性の B 型慢性肝炎の自然経過観 察例では女性に比し男性でより $\mathrm{HBe}$ 抗原の消失率が 高いことが，指摘されて $\overbrace{}^{8}$ 扣り，性別は $\mathrm{HBe}$ 抗原の陰 性化にとって必ずしも重要な要因とは考えられない．

B 型慢性肝炎での IFN 治療後の HBe 抗原の陰性 化率ないしは $\mathrm{HBe}$ 抗体への seroconversion 率は報 告者により異なるるののその成䋶は $13.0 \%$ 22.6\%で ある9．この成績はIFN 療法の効果としては必ずしも 满足すべきるのではない，そのため IFN 治療前にどの よ5な B 型慢性肝炎が IFN に反応性が高いのかを知 ることができればIFN 療法をより有效に行らことが できるものと考えられる。しかし，このよらな観点か ら見た IFN 治療前の組織学的検討は十分には行われ ていない。

今回の成績では IFN 治療後に HBe 抗原が持続的 に陰性化ないしは HBe 抗体へ seroconversion した 有効群では100\%に慢性肝炎活動性の組織診断基準て ある PN か認められた。また，PN の程度と IFN の有 効性との間には高い相関性が認められた。一方，IFN 投与後も持続的に $\mathrm{HBe}$ 抗原が陽性ないしは一過性に $\mathrm{HBe}$ 抗原が陰性化する無効群です65\%に PN が認め られた。

従って，PNはIFN 療法を有効に行らための必須条 件とはいえそれのみでは十分な治療前選択基準とはな らない，また，門脈域病变のらち炎症性細胞浸潤の強 いものに有効例が多いものの細胞浸潤の程度とは相関 しなかった。

一方, 肝実質病変では IFN の有効群で高率に認めら れた所見として BN (70\%) や肝細胞の腫大 (40\%) が あり，無效群での頻度はそれぞれ $46.6 \%$ と26.6\% と低 率であった。

また,肝細胞の腫大, BN および PN の組織所見を 2 つ以上認める B 型慢性肝炎では有意に高率に IFN が 有効であり，その組織所見も強いものが多かった。 た,これらの所見を認めない例ではIFN が無効であっ
た. 従ってこれらの組織所見はIFN 㞠法を行う際の 治療前選択基準の一つとなり得るものと考号られる.

一方， $\mathrm{HBe}$ 抗原陽性 B 型慢性肝炎の自然経過例の 検討では CAH p chronic lobular hepatitis で $\mathrm{HBe}$ 抗原の陰性化する例が多く, CPH では HBe 抗原の陰 性化は認められていないる)。また, これらの例では $\mathrm{HBe}$ 抗原の消失前の肝組織にて BN や肝細胞の变性壊死 の所見を高率に認めている ${ }^{10)}$ 。これらの知見は今回の 成䋶とよく一致するるのであり，広範な肝細胞障害を 有する慢性肝炎でIFN が有效であることを示してい る.

一方，BN や著明な PN を認める慢性肝炎では高率 に肝硬变へ進展することる知られている ${ }^{11,12)}$. そのた めIFN 療法はこれらの組織病変の改善も期待できる といら意味でも治療楽としての意義が大きい.

しかし，肝組織所見の改善には $\mathrm{HBe}$ 抗原の陰性化 のみではなく，血清トランスフミナーゼの正常化が必 要であり，たとえ HBe 抗体へ seroconversion しても 血清トランスアミナーゼの異常が持続する例では肝組 織所見の改善がみられないことはIFN 療法の効果判 定には HBV 関連マーカーのみではなく血清トランス アミナーゼの正常化す必要であることを示唆してい る.これらの事実はウイルスマーカーのない非A非B 型慢性肝炎にIFN 療法を行う際にも参考になる所見 であり，血清トランスアミナーゼの持続的な正常化が 治療効果の判定の指標となり得ることを示唆してい る $^{13)}$.

今後, ウイルス性慢性肝炎に IFN 療法を行う際の組 織学的適応基準としてPNのみではなく，BN や肝細 胞の腫大といった肝実質病变にも注目する必要があ る.

\section{結 語}

B 型慢性肝炎25例に IFN 療法を行いIFN の効果判 定を治療後に $\mathrm{HBe}$ 抗原が持続的に陰性化したものを 有効群 (10例) とし, HBe 抗原が持続的湯性または 一過性に陰性化するるのを無効群（15例）として以下 の知見を得た。

1. IFN 投与前の肝組織所見のうち無効群に比し有 効群で高率に認められた所見として PN $(100 \%), \mathrm{BN}$ （70\%）および肝細胞の腫大（40\%）があった。

2. 上記 3 つの組織所見を 2 つ以上有する B 型慢性 肝炎では有意に高率に IFN が有効であり，その組織所 見も強いるのが多かった。

3. IFN 治療後の肝生検では有効群で著明な組織学 
的改善を認めた。しかし, HBe 抗原が持続的に陽性の 例でる治療後に SGPT が正常化する例では組織学的 な改善が認められた。

\section{文 献}

1) Hoofnagle JH, Dusheiko GM, Seeff LB, et al : Seroconversion from hepatitis $\mathrm{Be}$ antigen to antibody in chronic type $B$ hepatitis. Ann Intern Med 94 : 744-748, 1981

2) Greenberg HB, Pollard RB, Lutwick LI, et al : Effect of human leukocyte interferon on hepatitis $B$ virus infection in patients with chronic active hepatitis. N Engl J Med 295 : 517-522, 1976

3）鉿木 宏, 市田文弘, 藤沢 洌, 他：HBe抗原陽 性慢性肝资に括けるインターフェロン- $\beta$ 療法。肝 胆膵 $9: 611-631,1984$

4) Dusheiko G, Dibisceglie A, Bowyer S, et al: Recombinant leukocyte interferon treatment of chronic hepatitis B. Hepatology 5: 556-560, 1985

5）奥野忠雄，中島年和，阿部芳道，他：B 型慢性肝炎 に対するインターフェロン単独療法後の長期経過 観察例の検討. 肝葴 $27: 1376-1383,1986$

6）鈴木宏，飯野四郎，市田文弘，他：Radioimmunoassay による e 抗原・e 抗体の測定について. 肝蔵 $21: 1304-1309,1980$
7) Smith CI, Merigan TC: Treatment of viral hepatitis: In Viral Hepatitis : Laboratory and Clinical Science Edited by Deinhardt F, Deinhardt J, Marcel Dekker Inc. New York, 1983, p491-512

8) Liaw Y-F, Chu C-M, Huang M-J, et al : Determinants for hepatitis Be antigen clearance in chronic type B hepatitis. Liver $4: 301-306,1984$

9）瀧野辰郎, 奥野忠雄, 阿部芳道, 他：B 型慢性肝炎 の治療. インターフェロン. 肝胆脺 $13: 503$ $-510,1986$

10) Liaw Y-F, Chu C-M, Su I-J, et al: Clinical and hepatological events preceding hepatitis $\mathrm{Be}$ antigen seroconversion in chronic type $B$ hepatitis. Gastroenterology 84 : 216-219, 1983

11) Okuno $T$, Okanoue $T$, Takino $T$, et al : Prognostic significance of bridging necrosis in chronic active hepatitis. Gastroenterol Jpn 18: 577-584, 1983

12) De Groote J, Fevery J, Lepoutre L : Long-term follow-up of chronic active hepatitis of moderate severity. Gut 19:510-513, 1978

13) Hoofnagle $\mathrm{JH}$, Mullen $\mathrm{KD}$, Jones $\mathrm{DB}$, et al: Treatment of chronic non- $A$, non- $B$ hepatitis with recombinant human alpha interferon. A preliminary report. N Engl J Med 315: 1575 $-1578,1986$ 


\title{
Pathological study of chronic hepatitis B with interferon treatment with special reference to the histopathological features predicting the efficacy of interferon treatment
}

\author{
Tadao OKuno*, Michiko Shindo, Masayuki Matsumoto, Makoto Takeda, \\ Ken ARAI and Tatsuro TAKINo**
}

The histopathological features of chronic hepatitis B were evaluated in 35 biopsy specimens from the 25 patients who had been treated with interferon (IFN). Twenty five biopsies were taken before IFN treatment. These 25 histological diagnoses were chronic active hepatitis (CAH) in 11, CAH with bridging necrosis $(\mathrm{BN})$ in 10 , chronic persistent hepatitis in 3 and cirrhosis in 1 . In 10 patients, $\mathrm{HBeAg}$ was persistently lost after IFN treatment (effective group) and in $15, \mathrm{HBeAg}$ remained positive or transiently lost (ineffective group). The pretreatment biopsies showed a significantly higher incidence of piecemeal necrosis and BN in the effective group than those in the ineffective $(p<0.01$ and $p<0.05$, respectively). The cases effective to IFN treatment had two or more histopathological features of $\mathrm{PN}$, BN and/or hepatocellular ballooning in the pretreatment biopsy $(p<0.01$ or $p<0.05$ ). The posttreatment biopsy was done in 8 . There was marked histological improvement after treatment.

* Department of Medicine, Akashi Municipal Hospital (Akashi)

** Third Department of Internal Medicine, Kyoto Prefectural University of Medicine (Kyoto) 